\title{
Access Structures in a Standard Translation Dictionary*
}

Phillip Adriaan Louw, Department of Afrikaans and Dutch, University of Stellenbosch, Stellenbosch, Republic of South Africa

Abstract: The access structure is the primary guide structure in the central texts of any standard translation dictionary. The metalexicographical term "guide structures" refers to the set of structures that provides a framework within which the accessibility and availability of information types in the dictionary can be evaluated.

The access structure is, however, not a singular entity. It includes certain substructures, of which the outer and inner access structures are the most important. In this article the status quo with regard to access structures in standard translation dictionaries with Afrikaans and English as treated language pair will be evaluated. Suggestions will then be made as to possible improvements.

In the discussion of the outer access structure it is suggested that the rapid outer access structure be improved by using an elementary thumb index and that the current system of running heads be retained. For the standard outer access structure a better planned and motivated system of ordering homonyms, as well as a more consistent initial alphabetical ordering is suggested.

The focus in the discussion of the inner access structure will be on improving the rapid inner access structure by an innovative use of typographical and non-typographical structural markers. Better systems of ordering information subtypes within information categories are suggested as an innovation in the standard inner access structure.

Broad guidelines are therefore given to improve dictionary accessibility and enhance userfriendliness through improved access structures.

Keywords: ACCESS STRUCTURE, DICTIONARY, DICTIONARY ACCESSIBILITY, HOMONYMY, INNER ACCESS STRUCTURE, INNER SEARCH PATH, LEXICOGRAPHY, METALEXICOGRAPHY, OUTER ACCESS STRUCTURE, OUTER SEARCH PATH, POLYSEMY, RAPID INNER ACCESS STRUCTURE, RAPID OUTER ACCESS STRUCTURE, STANDARD INNER ACCESS STRUCTURE, STANDARD OUTER ACCESS STRUCTURE, STANDARD TRANSLATION DICTIONARY, STRUCTURAL MARKER, USER-FRIENDLINESS

Opsomming: Toegangstrukture in 'n standaard vertalende woordeboek. Die toegangstruktuur is die primêre gidsstruktuur binne enige standaard vertalende woordeboek se sentrale tekste. Die metaleksikografiese term "gidsstrukture" verwys na die groep strukture wat 'n

This article is based on a paper read at the Third International Conference of the African Association for Lexicography, held at the Potchefstroom University for C.H.E., Potchefstroom, 29-30 June 1998. 
raamwerk verskaf waarbinne die toeganklikheid en bereikbaarheid van inligtingstipes in 'n woordeboek geëvalueer kan word.

Die toegangstruktuur is egter nie 'n ondeelbare entiteit nie. Dit sluit sekere substrukture in, waarvan die eksterne en interne toegangstrukture die belangrikste is. In hierdie artikel sal die status quo van toegangstrukture in huidige standaard vertalende woordeboeke met Afrikaans en Engels as behandelde taalpaar bespreek word. Voorstelle tot moontlike verbetering sal dan gemaak word.

By die bespreking van die eksterne toegangstruktuur word daar voorgestel dat die eksterne sneltoegangstruktuur verbeter word deur die gebruik van 'n eenvoudige duimindeks en dat die huidige stelsel van loopkoppe behou word. By die standaard eksteme toegangstruktuur word 'n meer deurdagte en beter gemotiveerde stelsel van homonimiese ordening, asook 'n meer konsekwente inisieel-alfabetiese ordening voorgestel.

Die fokus by die bespreking van die interne toegangstruktuur val op die verbetering van die interne sneltoegangstruktuur deur middel van 'n vernuwende gebruik van tipografiese en nietipografiese struktuurmerkers. Verbeterde ordeningstelsels binne inligtingskategorieë word voorgestel as 'n vernuwing in die standaard interne toegangstruktuur.

Breë riglyne word dus gegee om woordeboektoeganklikheid te verbeter en gebruikersvriendelikheid te verhoog deur verbeterde toegangstrukture.

Sleutelwoorde: EKSTERNE SNELTOEGANGSTRUKTUUR, EKSTERNE SOEKROETE, EKSTERNE TOEGANGSTRUKTUUR, GEBRUIKERSVRIENDELIKHEID, HOMONIMIE, INTERNE SNELTOEGANGSTRUKTUUR, INTERNE SOEKROETE, INTERNE TOEGANGSTRUKTUUR, LEKSIKOGRAFIE, METALEKSIKOGRAFIE, POLISEMIE, STANDAARD EKSTERNE TOEGANGSTRUKTUUR, STANDAARD INTERNE TOEGANGSTRUKTUUR, STANDAARD VERTALENDE WOORDEBOEK, STRUKTUURMERKER, TOEGANGSTRUKTUUR, WOORDEBOEK, WOORDEBOEKTOEGANKLIKHEID

The access structure is the primary guide structure in any standard translation dictionary's central texts. The term "guide structures" refers to the set of structures identified in metalexicography that provides a framework within which the accessibility and availability of information types in the dictionary can be evaluated.

The access structure is, however, not a singular entity. It encompasses certain substructures, of which the outer and inner access structures are the most important. In this article the access structures in standard translation dictionaries with Afrikaans and English as treated language pair will be evaluated and suggestions will be made as to possible improvements. Tweetalige Woordeboek / Bilingual Dictionary (BD) and Groot Woordeboek / Major Dictionary (MD), two desk dictionaries, will be taken as representative of this class in the absense of a true standard dictionary. The conception of a new standard translation dictionary will be advocated. The outer access structure will be discussed first. 


\section{The outer access structure}

\subsection{The outer search path}

User-friendliness is one of the most important focus points in current metalexicography. Ways in which the lexicographer can help the user to decode information more easily and quickly are therefore emphasized. On a structural level, changes can be made to access structures to ensure that they act as more effective guides to the user on his/her search paths to the desired information. To guide the user along the outer search path (that is the search up to the desired lemma), there should be a well-defined, easily understandable outer access structure.

The current outer access structures in bidirectional standard translation dictionaries with Afrikaans and English as treated language pair are not entirely successful. A new standard translation dictionary should note the successes, but address the failures by employing new, creative methods. A discussion of this necessary innovation requires smaller subdivisions of the outer access structure. A distinction may be made between the rapid outer access structure and the standard outer access structure.

\subsection{The rapid outer access structure}

The need to take the user to the lemma as quickly as possible requires a strictly pragmatic approach from the lexicographer. For example, this approach requires an initial alphabetical listing of lemmata. An elementary thumb index indicating the start of each alphabetical unit in both central texts of the bidirectional dictionary may improve the accessibility of the initial alphabetical listing. The thumb index is a part of the rapid outer access structure that is not used in either BD or MD, but could be employed in a new dictionary. The financial costs of such an innovation should, however, be kept in mind. If the additional costs alienate any part of the target user group, this system should be reconsidered.

Other vital elements of the rapid outer access structure should be employed on the search path from the start of an alphabetical unit to the lemma, namely running heads (Hausmann and Wiegand 1989: 338). These words indicate the first and last lemmata to be found on each page. The user's knowledge of alphabetical listing is relied upon. Users must be able to gauge immediately if the lemma they require can be found on the relevant page. The next step of the search can only begin thereafter.

The system of running heads is one of the few user-friendly guide systems that both BD and MD use consistently. Running heads are unfortunately the beginning and end of the rapid outer access structure in these dictionaries. In most other dictionaries the rapid outer access structure also ends here. Yet the Japanese dictionary makers, Kenkyusha, have created a marker of the rapid 
outer access structure that stretches to the lemma. Typographical innovation is combined with different colour printing in their Lighthouse series. The frequency of use of a lemma is indicated by means of a changing number of asterisks that are given as structural markers to the left of the lemma sign. These structural markers are supplemented by giving the most frequently used words in red print. For a more comprehensive discussion see Gouws (1996: 21).

A similar system is employed in the monolingual Collins COBUILD English Language Dictionary to show frequency of use of different lemmata. Here a grouping of blackened and empty diamonds in the margin to the right of the lemma shows its relative frequency of use. Each word that appears in their comprehensive corpus (The Bank of English) is marked by a band of 5 diamonds. The number of diamonds that are blackened denote the frequency of the lemma. Dozen, for example, is marked by four black diamonds showing that it is used far more frequently than dragoon which is marked by only one black diamond. These elements give rapid access to the lemmata and therefore provide help on the rapid outer search path. This is especially helpful when trying to build up a core vocabulary in a second or foreign language.

The Lighthouse and COBUILD series may be primarily aimed at the learner's market, but these innovations should be considered while setting up a new standard translation dictionary. The Reader's Digest Afrikaans-Engelse Woordeboek / English-Afrikaans Dictionary (henceforth RD) has already broken the South African mould by employing different colours of print, but with less success than the Lighthouse series. Structural markers in colours other than black, as well as structural markers such as COBUILD's can play an important role in the South African dictionary market in future, if lexicographers are prepared to change the status quo with regard to the rapid outer access structures of their dictionaries. Financial costs and the availability of suitable corpora will however play decisive roles.

\subsection{The standard outer access structure}

The rapid outer access structure provides rapid access along several parts of the user's outer search path. It may even lead right up to the lemma sign as is the case in the Lighthouse English-Japanese Dictionary and Collins COBUILD English Language Dictionary. Yet it cannot guide the user along the last, most vital part of the outer search path. The final choice of the desired macrostructural element is made by means of the standard outer access structure. This is also the case in BD and MD.

Both these dictionaries are monoaccessible. This implies that the standard outer access structure corresponds to the macrostructure in each part of the dictionary. This is not the case in $\mathrm{RD}$, where a group of texts called "Words in action / Woorde in aksie" is presented in the margins. Louw and Gouws (1996) show that these style and usage notes form a separate macrostructure in each central text of the dictionary, thereby making the dictionary polyaccessible. 
Tweetalige Aanleerderswoordeboek / Bilingual Learner's Dictionary (henceforth BLD) includes similar notes, but these are inserted as inner texts in the conventional macrostructures. See for example the treatment of flu.

\section{fu griep Griep is 'n siekte wat 'n mens gewoonlik in die winter kry. Flu is an illness which one usually gets in winter. \\ $\square$ fla nown (no plural) \\ fiu is an abbreviated, informal word for influenza}

It is advisable that BLD's example should currently be followed in South Africa, and that a standard translation dictionary should remain monoaccessible in each alphabetical macrostructure.

Initial alphabetical standard outer access structures are the norm in BD and MD. As far as possible, sublemmata are niched and not nested, thereby not disturbing the alphabetical listing. Nested sublemmata are semantically ideal, but currently niched sublemmata is the only plausible option. Haas's (1967) basic desideratum, that the best dictionary is one in which users find the required information in the first place they look, forms the foundation for this lexicographic practice.

Haas's point is also relevant to another important aspect of the standard outer access structure, viz. the order of homonyms. The markers denoting different homonyms are accepted as elements of the standard outer access structure. The underlying system by which these homonymous lemmata are put in order must however also be accepted as part of the standard outer access structure. The user who knows which system is used and how this system is implemented in a dictionary has a shortened search path.

A practical example of this is ordering using the principle of frequency of use. A mother-tongue speaker or good second language speaker who has a well-developed linguistic intuition and has read the user's guide, can unlock the desired information faster than others. The lexicographer may expect that users search for answers to their queries in the user's guide.

The user's guide interacts with the access structures to improve the dictionary's user-friendliness. BD and MD do not follow this norm of user-friendliness. Firstly, there does not seem to be an ordering system of homonyms according to frequency of use. Secondly, their user's guides do not provide any explanation for their system of ordering and of semantic relations such as homonymy and polysemy. Without a good guide this aspect of the dictionary's outer access structure loses almost all its value. The problem is even more pressing in the case of the inner access structure.

An example of the successful integration of the user's guide with innovation in the outer and inner access structures of a dictionary is the monolingual Cambridge International Dictionary of English (henceforth CIDE). CIDE gives an 
interesting alternative to the prototypical marking of homonymy on the level of the standard outer access structure. Just to the right of the lemma guide words are given in rectangular frames. These guide words are usually a single key word or phrase taken from the lemma's definiens. They are intended to help the user to make an immediate choice of the correct lemma.

CIDE's splitting approach has unfortunately led to a situation where the basic semantic difference between homonymy and polysemy is denied, but a large measure of communicative value is maintained by the strength of these guide words as elements of the access structure, as is illustrated by the treatment of par.

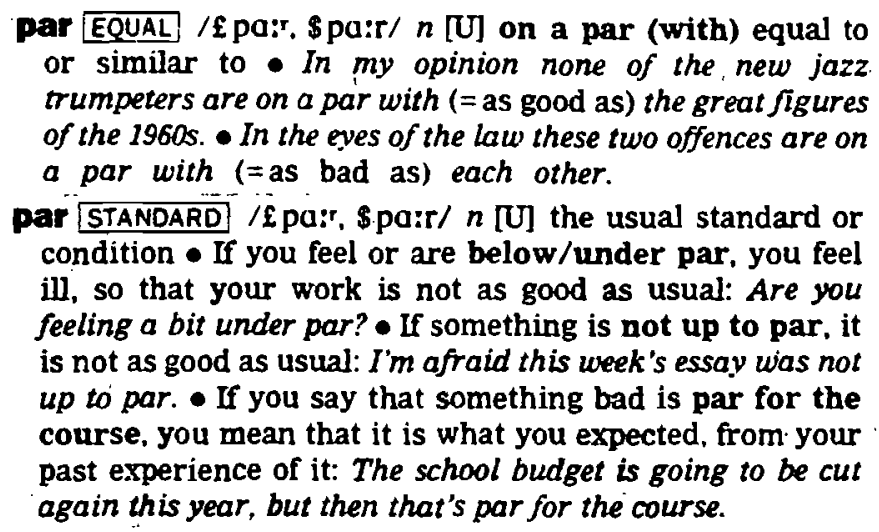

The fact that this system is explained simply and effectively to the target user (who is obviously not a linguist) in both the preface and user's guides is further evidence of CIDE's user-orientated åpproach.

The use of guide words as formal elements of the standard outer access structure of the dictionary can add an important dimension to a standard translation dictionary. The lexicographer will however have to decide what manner of addressing the user these entries should have and therefore in what language they should be presented. Be it in English or in Afrikaans, the success of this system will depend on a consistent application and thorough explanation in the user's guide. These crucial principles also hold true for the inner access structure.

\section{The inner access structure}

\subsection{The inner search path}

The inner access structure has as its main goal to, as Gouws (1996: 19) puts it, "help the user to reach the specific information categories within the article". The complexity of the microstructure and the number of information categories 
that it encompasses necessarily make the user's inner search path more difficult. A good inner access structure must employ structural markers to lead the user on this inner search path. These markers are mostly either foreign markers or markers known to users, but used outside of their normal context. The creative use of already known markers confuse users by unnecessarily increasing the dictionary's textual condensation. Interaction between the inner access structure and the user's guide is here of the utmost importance. Hausmann and Wiegand (1989: 338) state that "most metatexts explain the inner access structure". This is however not the case in the canonical South African translation dictionaries.

\subsection{The rapid inner access structure}

$\mathrm{BD}$ and MD continuously ignore elementary principles of user-friendliness. Structural markers are encoded in the dictionary, but the users are expected to decode these markers without the necessary help. The problem can also lie on the other side of the scale. Information can be provided, but without clear structural markers to guide the user to that specific information category.

In both $\mathrm{BD}$ and $\mathrm{MD}$ a workable inner access structure and especially a rapid inner access structure is lacking. A lack of structural markers can lead to a frustrating and unsuccessful simulated question and answer dialogue between the lexicographer and the user. In any new standard translation dictionary, structural markers as elements of the rapid inner access structure will determine the success of the user's inner search path.

\subsubsection{Structural markers}

Gouws (1996: 23) defines the role of structural markers as follows: "Structural markers ... indicate the borders between information categories as well as the position and scope of different search areas." This premise leaves enough room to broaden the scope of the term "structural marker" to include the elements of the access structure that indicate semantic relations.

A new system of structural markers should for example be employed to indicate different equivalents for different senses of the lemma, as opposed to different equivalents for different usages of the lemma or other partially synonymous translation equivalents. A system based on the numerical and letter systems used in monolingual dictionaries should replace the confusing system of semicolons and commas currently used in BD and MD. If some of the old methods are integrated with the new approach, structural markers that function as indicators can help to provide rapid access to the correct equivalent. A good system of indication will have to be combined with consistently applied sense and equivalent discrimination. The user's guide will also have to explain every structural marker used. 
There are more conventional structural markers that form part of the rapid inner access structure. These fall into two main categories, viz. non-typographical and typographical structural markers.

Non-typographical structural markers are special markers such as frames, coloured blocks and diamonds that introduce separate information categories. Despite BD and MD's lack of these vital markers there are some precedents in South African practical lexicography. Gouws (1996: 23-25), for example, focuses on two.

BLD employs a coloured diamond to distinguish collocations from other examples within the broader category of examples. These collocations obtain the status of separate treatment units and should therefore be made as accessible as possible. They can create further problems in that they can have their own translations that are in no way related to the equivalents given for the lemma or sense of the lemma. See for example the treatment of due to as a collocation in BLD. The translation "te danke aan" bears no relation to "aankom" that is given for the lemma due. Collocations are mostly complex independent entities that require separate treatment from example sentences that have the lemma and/or the translation equivalent as address. It is therefore imperative that a structural marker with unique reference be used to provide rapid access to this information category.

Information categories other than collocations should also be introduced by structural markers. The most prominent of these is grammatical information. Gouws (1996) refers specifically to the Verklarende Handwoordeboek van die Afrikaanse Taal (HAT) that uses an empty quadrangular frame to mark different parts of speech in which the lemma can function. A similar system is also employed in BLD.

These markers are valuable because they give rapid access to information on parts of speech. Yet they can only be effective if the user actually understands the system. When non-typographical markers are used, it is important that there is good interaction between the rapid inner access structure and the user's guide of a specific dictionary. The function of each of the structural markers should be explained simply and carefully.

The rapid inner access structure should also interact with the key element of the microstructure, viz. semantic information. The role of markers for semantic relations has already been discussed, but there is another information subcategory that needs structural markers. This subcategory is semantic and contextual guidance in the form of sense and equivalent discrimination. As a non-typographical structural marker, CIDE's guide word in a frame can be used to denote sense discrimination. This means that the form (e.g. the frame) of CIDE's guide words can be transformed into an element of the rapid inner access structure that gives rapid access to the explanation of each sense which in turn gives access to the correct translation equivalent. This marker should combine with a numerical marker indicating source language polysemy to create an effective marker of the rapid inner access structure. The frame depends 
on the number to prevent a confusing system such as the one that is found in CIDE.

The value of non-typographical structural markers with semantic and contextual guidance is not limited to sense discrimination. Equivalent discrimination can also form a separate information subcategory and should be introduced by a non-typographical structural marker. Both BD and MD have context or co-text words or phrases that act as equivalent discrimination either for different equivalents for different senses of the lemma or within target language synonym paradigms. See for example the treatment of stuk in MD.

\section{stuk, (-ke), piece (of bread); fragment, chip (of glass); _ chunk (of lead); play (stage)}

These words or phrases are in the target language, have the translation equivalent as address and usually appear in the article position directly after the equivalent. In both $\mathrm{BD}$ and MD they are placed in brackets, which act as structural markers that give rapid access to the information. Other information categories in MD are also placed in brackets. Brackets could also function in their normal syntactic use in some of the example sentences. They can therefore lose their value as unique structural markers.

Any new systems of contextual and semantic guidance should interact with structural markers with unique reference to avoid confusing the user. Typographical structural markers should be used in addition to the non-typographical markers. Different font types and sizes, bold print, capital letters and italics can all be used to aid fast and effective identification of a specific information type. Once again these markers have to be explained thoroughly in the user's guide. The lexicographer has to be careful in the choice and application of the chosen markers, because too many foreign, complex markers can increase the textual condensation unnecessarily and make the dictionary less user-friendly.

$\mathrm{BD}$ and $\mathrm{MD}$ do use some effective structural markers such as the typographical marking of examples and the presentation in capital letters or bold type of a key word in each of these examples. Unfortunately too little is done to establish truly effective systems of structural markers and accordingly truly effective rapid inner access structures.

\subsection{The standard inner access structure}

The standard inner access structure should share in the spirit of innovation. Methods of microstructural ordering should be determined empirically by 
means of questionnaires, interviews, etc. that form part of dictionary planning. This will ensure that the ordering of senses and synonyms that suit the target user best will be employed. These systems should then be applied consistently in the dictionary.

It is not only ordering in information subcategories though that is relevant, but also ordering in the dictionary article as a whole. At this point the standard inner access structure overlaps with the article structure. The choices made as to the utilization of certain article positions should be carefully planned and well-motivated in the user's guide.

\section{Conclusion}

Should the inner access structure be an effective guide in the search for among others help with pronunciation, communicative equivalence and pragmatic contextualisation, the dictionary will certainly be employed optimally as text and as text-type carrier. If this inner access structure is combined with an effective, transparent outer access structure a high standard of user-friendliness and dictionary accessibility can be set. Sadly, neither BD nor MD has reached this point.

Bilingual dictionaries are of pivotal importance in South Africa. They need to bridge cultural and semantic gaps in our multicultural society. Yet this cannot be achieved if the users are frustrated in their efforts to find relevant information. Lessons should be learnt from the innovative approaches taken in the compilation of other dictionaries.

\section{Bibliography}

\section{A. Dictionaries}

Bosman, D.B. et al. 1984. Tweetalige Woordeboek / Bilingual Dictionary. Cape Town: Tafelberg.

Du Plessis, M. 1993. Tweetalige Aanleerderswoordeboek / Bilingual Leamer's Dictionary. Cape Town: Tafelberg.

Grobbelaar, P. (Ed.). 1987. Reader's Digest Afrikaans-Engelse Woordeboek / English-Afrikaans Dictionary. Cape Town: The Reader's Digest Association.

Kritzinger, M.S.B. et al. $1986^{13}$. Groot Woordeboek / Major Dictionary. Pretoria: J.L. van Schaik.

Odendal, F.F. 1994. Verklarende Handwoordeboek van die Afrikaanse Taal. Doomfontein: Perskor.

Procter, P. et al. (Eds.). 1995. Cambridge International Dictionary of English. Cambridge: Cambridge International Press.

Sinclair, J. et al. (Eds.). 1995. Collins COBUILD English Language Dictionary. London: HarperCollins.

Takebayashi, S. and Y. Kojima (Eds.). 1990. Kenkyusha's Lighthouse English-japanese Dictionary. Tokyo: Kenkyusha. 


\section{B. Other sources}

Gouws, R.H. 1996. Bilingual Dictionaries and Communicative Equivalence for a Multilingual Society. Lexikos 6: 14-31.

Haas, M. 1967. What Belongs in a Bilingual Dictionary? Householder, F.W. and Sol Saporta (Eds.). 1967: 45-50.

Hausmann, Franz J. and Herbert E. Wiegand. 1989. Component Parts and Structures of Monolingual Dictionaries. Hausmann et al. 1989-1991: 328-360.

Hausmann, Franz J., Oskar Reichmann, Herbert E. Wiegand and Ladislav Zgusta (Eds.). 1989 1991. Wörterbücher: Ein internationales Handbuch zur Lexikographie / Dictionaries: An International Encyclopedia of Lexicography / Dictionnaires: Encyclopédie internationale de lexicographie. Berlin: Walter de Gruyter.

Householder, F.W. and Sol Saporta (Eds.). 1967. Problems in Lexicography. Bloomington: Indiana University.

Louw, P.A. and R.H. Gouws. 1996. Lemmatiese en nielemmatiese adressering in Afrikaanse vertalende woordeboeke. South African Journal of Linguistics 14(3): 92-100, August 1996. 